\title{
A STRUCTURAL EQUATION MODEL ON COMMUNICATIVE ABILITY OF STUDENTS IN SENIOR HIGH SCHOOL
}

\author{
Jesyl F. Avanceña ${ }^{1}$, Elleine Rose A. Oliva, Ed.D. ${ }^{2}$
}

Article DOI: https://doi.org/10.36713/epra9387

DOI No: 10.36713/epra9387

\begin{abstract}
This study aimed to ascertain the most appropriate model for students' communication abilities. Additionally, a significant relationship between the exogenous variables of teaching ability, classroom learning, and student engagement and the endogenous variable of communicative ability must be established. Additionally, this non-experimental and correlational research design and structural model identify the most appropriate model of communicative ability. As a result, a stratified random sampling technique was used to select 442 participants from senior high school students in Region XI public schools in the eleventh and twelfth grades. As a result, the following statistical techniques were used: mean, Pearson r, regression, and Structural Equation Model (SEM). Exogenous variables exhibit a significant correlation with endogenous variables, with the fifth model indicating the highest correlation. Exogenous variables, on the other hand, achieved the highest descriptive level. The endogenous variable acquired a descriptive level of highest motivation in language learning, which included the following: positive classroom, varied appreciation, personal recognition, and majority resilience; student engagement: learning preferences, school preferences, effort and persistence, extracurricular activities, and cognitive participation; and the endogenous variable acquired a descriptive level of highest motivation in language learning, which included the following: teaching methodology, teacher perspective, teacher role, the impact of communicative language teaching on communicative ability, ease, and acceptability communication, and classroom observation.
\end{abstract}

KEYWORDS: education, teaching skills, classroom learning, student engagement, communicative skills, structural framework model, Philippines

\section{INTRODUCTION}

It is a barrier to the increase in students' lack of communicative ability as a result of the low quality of teachers' expertise in honing their communication. Thus, according to the global study, educational standards have deteriorated significantly in communicative ability (Darko, Denbake, and Forson, 1997). Additionally, the students did not develop a sense of comfort with communication, which acted as a barrier to lowering their communicative ability level. Meanwhile, according to a study conducted by (Owusu - Ansah 2015), students' ability to communicate effectively decreases as a result of a lack of appropriate grammatical rules.

Additionally, students must develop communication skills to hone their interpersonal communication abilities (Felicilda, Felicilda, and Tabaag, 2019). In this regard, communication skills are one of the learning skills that must be developed to improve their speaking fluency. On the other hand, an appropriate task should be assigned to students as a way for teachers to mold their communicative ability and fully hone their communication skills with their classmates.

However, the teacher's ability to teach is critical in raising the students' level of communicative ability (Kirinic, Dvorsky, and Bakic-Tomic, 2015). However, the current study (Bergil, 2016) agrees that students who acquire speaking skills through high-quality material are beneficial as a part of the classroom environment for their comprehensive learning.

As a result, while there are studies on communication abilities, there are none on teaching ability, learning environment, or student interaction using the structural equation model. which is a dependable approach to developing communicative abilities. The teaching ability, learning environment, and student interactions will all improve when each student develops the communicative ability, the most effective weapon in all human interactions. The researcher recommended examining variables that could aid in research on local and global 
awareness and diverse research on connections to establish a solid foundation for students' communicative skills.

\section{RESEARCH OBJECTIVES}

This study aims to determine and develop a structural model of communication ability. The study ensured the following objectives:

1. Determine the level teachers in teaching ability based on:

1.1 planning;

1.2 development and

1.3 results.

2. Determine the level of classroom learning of students based on:

2.1 positive classroom;

2.2 different appreciation;

2.3 personal recognition and

2.4 majority stability

3. Determine the level of student engagement based on:

3.1. learning preferences;

3.2 school preferences;

3.3 effort and persistence

3.4 extracurricular activities and

3.5 informational participation

4. Determine the level of communicative ability of students based on:

4.1. teaching methods;

4.2. teacher perspective;

4.3. teacher role;

4.4. impact of communicative language teaching on communicative ability;

4.5. ease and acceptable communication and

4.6. classroom observations

5. Determine the significant relationship between:

5.1 teaching skills and communicative skills;

5.2 classroom learning and communicative skills and

5.3 student interaction and communicative ability

6. Recognize the combined and single influence of teacher teaching ability, classroom learning, and students' interaction on communicative skills.

7. Determine the most appropriate model for the communicative ability of students.

\section{HYPOTHESIS}

The null hypotheses of this study were developed and tested at a 0.05 level of significance in which:

1. There is a significant relationship between:

1.1. teacher teaching ability and communicative ability;

1.2. classroom learning and communicative skills and

1.3. student interaction and communicative ability.

2. Teacher teaching ability, classroom learning, and students 'interactions have no significant influence on students' communicative skills.

3. There is no most appropriate model for students' communicative skills.

\section{METHODOLOGY}

The design of this study is descriptive, correlational, and causal-comparative. It describes the state of affairs that would exist during the actual research to investigate the causes of a particular problem involving individuals whose responses are continuous data. Additionally, a structural estimation model was used to determine the correlation between each variable in this study (Gill, 2012). The descriptive correlational research design is concerned with establishing and establishing a predictive relationship. It uses two or more data sets to determine the significance of each variable's correlation. Additionally, this study compared other statistical methods using the Structural Equation Model (SEM). Additionally, a structural equation model is one of the more complex data analysis techniques because it establishes a structure for the covariance between modified variables, hence the alternative name covariance structure modeling, thus producing more meaningful and valid results (Byrne, 2012).

This descriptive study analyzed quantitative data about the problem, as mentioned earlier. The quantitative aspect is a data collection technique appropriate for identifying respondents who responded to the 
questions. The data collection procedure is based on the administration of questionnaires. This research aims to develop and apply linguistic models, theories, and hypotheses to the problem at hand. It contains empirical data on respondents' scale differences in teaching ability, classroom learning environment, student engagement, and communicative ability. The purpose of this research was to adapt the data to fit hit models in teaching ability, classroom learning environment, student engagement, and communicative ability. Thus, this causal design elucidates the relationship between the research's overt and covert variables (Hasman, 2015). As a result, when the hypothesized model is rejected due to its statistical fit, an alternate model that fits the data must be developed (Bollen, Chen, Curran, Kirby, and Paxton 2008).

\section{SAMPLING DESIGN}

According to the study's objective, the design of this study is a quantitative research method for data collection that describes the relationship between a numerical value measured systematically and the communicative ability of Senior High School students in Region XI public schools. It assessed the communicative ability of 442 Senior High School students from ten of Region XI's eleven regional departments of education in the 2020-2021 school year. However, to determine the appropriate number of respondents for the Structural Estimation Model, Slovin's formula was used, with a maximum sample size of 400 and a.05 level of significance.

Additionally, the sample size for the Structural Forecast Model is a reliable attempt (Ogunlana, Ogunsami, and Oke, 2017). They indicated that a sample size of 300-400 individuals would be consistent with the Structural Model. Additionally, it was proposed that there should be 200 but no more than 400 test sizes (Bacon, 1998). However, when the sample size exceeds 400 to 500 participants, the Model Structural Evaluation analysis becomes cumbersome. As a result, the Structural Model Study will require between 200 and 400 hours (Von Der Heidt and Scott, 2007). On the other hand, some scholars argue that the sample size is relatively independent of the population's size or smallness (Sergiovane, 2015).

As a result, it made no difference whether the sample size was large or small. The researchers chose to consider the 442 respondents from ten schools across ten divisions of the Department of Education in Region XI. The researcher used stratified random sampling to determine the number of students in each division of the Department of Education of Region XI, who have an equal chance of being selected as a research respondent through stratified random sampling (Fraenkel and Hyun, 2012). Random sampling ensured that all population members had an equal chance of being chosen as the sample unit (David, 2002).

\section{STATISTICAL DESIGN}

The statistical tools used for data analysis and interpretation were as follows:

Mean. It determines the level of teaching ability, classroom learning environment, student interactions, and communicative ability.

Standard Deviation. It is to measure the fragmentation of a frequency distribution.

Pearson Product Moment Correlation. It is used to determine the significant relationship between teaching ability, classroom learning environment, student engagement, and communicative ability.

Multiple Regression. It is to determine the significant predictor of communicative ability.

Structural Equation Model (SEM). It uses to search for the best and most appropriate model. In analyzing the factors, it is necessary to conduct factor analysis on the hidden variables that suggested a cut-off value of 0.50 . At the same time (Ullman and Bentler, 2012) used 0.45 in modeling the construction safety culture. The essence of the test based on (Savalei and Bentler, 2010) is to ensure the elimination of traits with low correlations with traits of other hidden factors in the final SEM. The sample size affects the cut-off value, but a range of 0.45 to 0.50 is considered appropriate. Furthermore, this tool was used to determine the model that best suited the organizational capability.

The goodness of Fit Statistics for Alternative Model through Analysis of Moment Structure (AMOS). All stated essential indicators must be consistent with the subsequent premise to determine the most appropriate model.

Chi Square/Degree of Freedom (CMIN/DF) $0<$ value $<2$

P Value> .05

Normative Fit Index (NFI)> .95

Comparative Fit Index (CFI)> .95

Goodness of Fit Index (GFI)> .95

Tucker-Lewis Index $>.95$

Root Mean Square Error of Approximation (RMSEA) <.05

P-close $>.50$ 


\section{GEOGRAPHICAL AREA}

The purpose of this research is to ascertain the communicative ability of students in selected Senior High Schools in Region XI, which encompasses the cities of Davao, Davao City, Davao del Norte, Davao del Sur, Davao Occidental, Davao Oriental, and Davao de Oro. Region XI encountered an issue with students' communication abilities. Many students are afraid to speak in public due to their limited communicative ability. Additionally, the researcher was interested in determining the extent to which teaching ability, classroom learning environment, and student engagement are associated with Region XI's communication ability. The research used a map of Davao city to pinpoint the locations of public schools, including Senior High School. Davao City is the Philippines' largest city by land area and the highest population outside the Metro.

\section{RESULTS}

This study describes how the structural standard model of communicative competence was developed and validated through instructional ability, classroom learning environment, and student engagement. As a result of the analysis and interpretation of the data gathered, the objectives were met.

\section{Teacher Teaching Competency Level}

Table 1 shows the first variable on the level of the teacher's teaching ability presented variable of its indicators as shown in the attached questionnaire are also analyzed and interpreted. In addition, table 1 reveals the level of teaching competency with a total mean score of 4.38 as the highest with a standard deviation of 0.51 . It shows that the indicator with the highest mean of 4.39 as the highest is the result. Meanwhile, the planning indicators got the lowest mean score of 4.37 , described as the highest descriptive level.

Table 1

Teacher Teaching Competency Level

\begin{tabular}{lccc}
\hline Indicator & SD & Mean & Descriptive Level \\
\hline Planning & 0.60 & 4.37 & Very High \\
Progress & 0.53 & 4.38 & Very High \\
Result & 0.56 & 4.39 & Very High \\
Total & $\mathbf{0 . 5 1}$ & $\mathbf{4 . 3 8}$ & Very High
\end{tabular}

\section{Classroom Learning Level}

The level of the classroom learning environment in Table 2 and each indicator was analyzed and interpreted. Table 2 presented the results based on the level of classroom learning environment with a total mean of 4.40 as very high with a standard deviation of 0.51 . It shows the mean of 4.43 as very high is the positive classroom. However, the one with the lowest mean indicator of 4.38 as very high is the majority stability.

Table 2

Classroom Learning Level

\begin{tabular}{lccl}
\hline Indicator & SD & Mean & Descriptive Level \\
\hline Positive Classroom & 0.53 & 4.43 & Very High \\
Variety of Appreciation & 0.59 & 4.39 & Very High \\
Personal Acknowledgment & 0.60 & 4.40 & Very High \\
Majority Stability & 0.64 & 4.38 & Very High \\
Total & $\mathbf{0 . 5 1}$ & $\mathbf{4 . 4 0}$ & Very High
\end{tabular}

\section{Level of Student Engagement}

The engagement level of the students had five indicators shown in Table 3 as a very high descriptive level with a total mean of 4.33 and a standard deviation of 0.52 . The result shows that the one with the highest mean score indicator of 4.51 described as the very high level is school preference. The lowest mean of 4.07 that as high is an extracurricular activity. 
EPRA International Journal of Multidisciplinary Research (IJMR) - Peer Reviewed Journal

Volume: 8| Issue: 1| January 2022|| Journal DOI: 10.36713/epra2013 || SJIF Impact Factor 2021: 8.047 || ISI Value: 1.188

Table 3

Level of Student Engagement

\begin{tabular}{lccl}
\hline Indicator & SD & Mean & Descriptive Level \\
\hline Learning Preference & 0.60 & 4.47 & Very High \\
School Preference & 0.63 & 4.51 & Very High \\
Effort and Perseverance & 0.56 & 4.30 & Very High \\
Extracurricular Activities & 0.84 & 4.07 & High \\
Informational Participation & 0.62 & 4.32 & Very High \\
Total & 0.52 & 4.33 & Very High
\end{tabular}

\section{Level of Communicative Ability}

The level of communication ability of the students with six indicators had a total mean of 4.38 and a standard deviation of 0.51 . The result shows that the indicator with the highest mean of 4.43 is the classroom observation got a very high description. While the teaching method indicator with the lowest mean score of 4.31 a very high.

Table 4

Level of Communicative Ability

\begin{tabular}{llll}
\multicolumn{1}{c}{ Indicator } & SD & Mean & Descriptive Level \\
\hline Teaching Methods & 0.61 & 4.31 & Very High \\
Teacher Perspective & 0.56 & 4.35 & Very High \\
$\begin{array}{l}\text { Teacher Role } \\
\begin{array}{l}\text { Impact of Communicative } \\
\text { Language Teaching on } \\
\text { Communicative Ability }\end{array}\end{array}$ & 0.61 & 4.41 & Very High \\
$\begin{array}{l}\text { Ease and Acceptance of } \\
\text { Communication }\end{array}$ & 0.58 & 4.39 & Very High \\
Classroom Observation & 0.57 & & Very High \\
Total & 0.56 & 4.33 & Very High \\
& $\mathbf{0 . 5 1}$ & 4.43 & Very High
\end{tabular}

\section{Significant Relationship Between Ability in Teacher Instruction and Communicative Skills}

The significant relationship between teaching ability and communicative ability is in Table 5.1 with a total $r$-value of .747 corresponding probability of $p<.000$ is less than the 0.05 level of significance set in the study. In addition, the null hypothesis is therefore unacceptable and states that there is a significant correlation between the teaching ability and the communicative ability of the students. Suggests that very high levels of teaching ability can result in very high levels of communicative skill. Further, it is noticeably shown in the data that planning, development, and outcome indicators of teaching ability, when correlated with teaching method, the total r-value is .638 with p-value $<0.05$ significant. When indicators of teaching ability with the teacher's perspective, the total $\mathrm{r}$-value is .692 with p-value $<0.05$; therefore, significant. When indicators of teaching ability are associated with teacher performance, it has a total $r$-value of .644 with a $p$-value $<0.05$, therefore, significant. 
EPRA International Journal of Multidisciplinary Research (IJMR) - Peer Reviewed Journal

Volume: 8| Issue: 1| January 2022|| Journal DOI: 10.36713/epra2013 || SJIF Impact Factor 2021: 8.047 || ISI Value: 1.188

\section{Table 5.1}

Significant Relationship Between Teacher Teaching Ability and Communicative Ability Teaching Skills Communicative Skills

\begin{tabular}{|c|c|c|c|c|c|c|c|}
\hline \multirow{2}{*}{$\begin{array}{c}\text { Teaching } \\
\text { Ability }\end{array}$} & \multicolumn{7}{|c|}{ Communicate Skills } \\
\hline & PM & PW & GG & IK & $\mathbf{P I}$ & $\mathbf{O K}$ & Total \\
\hline Planning & $\begin{array}{l}.502^{* *} \\
.000\end{array}$ & $\begin{array}{l}.566^{* *} \\
.000\end{array}$ & $\begin{array}{l}.494^{* *} \\
.000\end{array}$ & $\begin{array}{l}.490^{* *} \\
.000\end{array}$ & $\begin{array}{l}.522^{* *} \\
.000\end{array}$ & $\begin{array}{l}.558^{* *} \\
.000\end{array}$ & $\begin{array}{l}.582^{* *} \\
.000\end{array}$ \\
\hline Progress & $\begin{array}{l}.623^{* *} \\
.000\end{array}$ & $\begin{array}{l}.682^{* *} \\
.000\end{array}$ & $\begin{array}{l}.638^{* *} \\
.000\end{array}$ & $\begin{array}{l}.634^{\text {** }} \\
.000\end{array}$ & $\begin{array}{l}.648^{* *} \\
.000\end{array}$ & $\begin{array}{l}.687^{* *} \\
.000\end{array}$ & $\begin{array}{l}.733^{* *} \\
.000\end{array}$ \\
\hline Result & $\begin{array}{l}.615^{* *} \\
.000\end{array}$ & $\begin{array}{l}.640^{* *} \\
.000\end{array}$ & $\begin{array}{l}.628^{* *} \\
.000\end{array}$ & $\begin{array}{l}.647^{* *} \\
.000\end{array}$ & $\begin{array}{l}.657^{* *} \\
.000\end{array}$ & $\begin{array}{l}.650^{* *} \\
.000\end{array}$ & $\begin{array}{l}.7266^{* * *} \\
.000\end{array}$ \\
\hline Total & $\begin{array}{l}.638^{* *} \\
.000\end{array}$ & $\begin{array}{l}.692^{* *} \\
.000\end{array}$ & $\begin{array}{l}.644^{* * *} \\
.000\end{array}$ & $\begin{array}{l}.649^{* *} \\
.000\end{array}$ & $\begin{array}{l}.669^{* *} \\
.000\end{array}$ & $\begin{array}{l}.694^{* *} \\
.000\end{array}$ & $\begin{array}{l}.747^{* *} \\
.000\end{array}$ \\
\hline
\end{tabular}

*Significant at .05 significant level

Legend:

PM - teaching methods

PW - teacher's perspective

GG - teacher role

IK - the impact of communicative language teaching on communicative ability

PI - ease and acceptable communication

OK - classroom observations

The indicators of instructional ability are correlated with the impact of communicative language teaching on communicative ability with an R-value of .649 with a p-value $<0.05$; this means significance. When the indicators of instructional ability with ease and acceptability of communication are correlated with an Rvalue of .669 with a p-value $<0.05$, it still means significance. Finally, when the indicator of teaching ability is connected with classroom observation with an R-value of .694 with a p-value $<0.05$, it is still significant.

\section{Significant Relationship Between Learning Classroom and Communicative Ability}

The significant relationship between classroom learning environment and communicative ability. Table 5.2 with a total R-value of .707 and the corresponding probability of $p<.000$ is less than the 0.05 level of significance set in the study. However, the null hypothesis is unacceptable and states a significant correlation between classroom learning and communicative skills. Furthermore, this suggests that very high levels of teaching ability can result in very high levels of communicative skill. Significantly the data showed that positive classroom, varying esteem, personal recognition, and stability were indicators of the classroom learning environment correlated with the teaching method with a total R-value was .597 with $\mathrm{p}$-value $<0.05$, therefore, significant. Thus,

Table 5.2

Significant Relationship Between Classroom Learning and Communicative Ability

\begin{tabular}{|c|c|c|c|c|c|c|c|}
\hline \multirow{2}{*}{$\begin{array}{l}\text { Classroom } \\
\text { Learning }\end{array}$} & \multicolumn{7}{|c|}{ Communicative Ability } \\
\hline & $\mathrm{PM}$ & $\mathrm{PW}$ & GG & $\mathrm{IK}$ & PI & $\mathrm{OK}$ & Total \\
\hline Positive Classroom & $\begin{array}{l}.632^{* *} \\
.000\end{array}$ & $\begin{array}{l}.673^{* *} \\
.000\end{array}$ & $\begin{array}{l}.645^{* *} \\
.000\end{array}$ & $\begin{array}{l}.601^{* *} \\
.000\end{array}$ & $\begin{array}{l}.663^{* *} \\
.000\end{array}$ & $\begin{array}{l}.685^{* *} \\
.000\end{array}$ & $\begin{array}{l}.732^{* *} \\
.000\end{array}$ \\
\hline Different & $.558^{* *}$ & $.595^{* *}$ & $.534^{* *}$ & $.535^{* *}$ & $.581^{* *}$ & $.588^{* *}$ & $.634^{* * *}$ \\
\hline Appreciation & .000 & .000 & .000 & .000 & .000 & .000 & .000 \\
\hline $\begin{array}{l}\text { Personal } \\
\text { Recognition }\end{array}$ & $\begin{array}{l}.439^{* *} \\
.000\end{array}$ & $\begin{array}{l}.513^{* *} \\
.000\end{array}$ & $\begin{array}{l}.487^{* *} \\
.000\end{array}$ & $\begin{array}{l}.434^{* *} \\
.000\end{array}$ & $\begin{array}{l}.493^{* *} \\
.000\end{array}$ & $\begin{array}{l}.503^{* *} \\
.000\end{array}$ & $\begin{array}{l}.535^{* *} \\
.000\end{array}$ \\
\hline
\end{tabular}


EPRA International Journal of Multidisciplinary Research (IJMR) - Peer Reviewed Journal

Volume: 8| Issue: 1| January 2022|| Journal DOI: 10.36713/epra2013 || SJIF Impact Factor 2021: 8.047 || ISI Value: 1.188

$\begin{array}{cccccccc} & & & & \\ \text { Majority Stability } & .446^{* *} & .525^{* *} & .473^{* *} & .479^{* *} & .506^{* *} & .525^{* *} & \mathbf{. 5 5 1}^{* *} \\ & .000 & .000 & .000 & .000 & .000 & .000 & \mathbf{. 0 0 0}^{*} \\ & & & & & & & \\ \text { Total } & \mathbf{. 5 9 7} & \mathbf{. 6 6 6 * *} & \mathbf{. 6 1 7}^{* *} & \mathbf{. 5 9}^{* *} & \mathbf{. 6 4 7}^{* *} & \mathbf{. 6 3}^{* *} & \mathbf{. 7 0 7}^{* *} \\ & \mathbf{. 0 0 0} & \mathbf{. 0 0 0} & \mathbf{. 0 0 0} & \mathbf{. 0 0 0} & \mathbf{. 0 0 0} & \mathbf{. 0 0 0} & \mathbf{. 0 0 0}^{*}\end{array}$

\footnotetext{
*Significant at .05 significant level

Legend:

PM - teaching methods

PW - teacher's perspective

GG - teacher role

IK - the impact of communicative language teaching on communicative ability

PI - ease and acceptable communication

OK - classroom observations
}

An indicator of the classroom learning environment is from the teachers' perspective, with a total R-value of .666 with a p-value $<0.05$. Therefore, significant indicators of the classroom learning environment are correlated with the teacher's role with a total R-value of .617 with a $\mathrm{p}$-value $<0.05$; therefore, it is significant. When the classroom learning environment indicators are correlated with the impact of communicative language teaching on communicative ability with a total $\mathrm{R}$-value of .592 with a $\mathrm{p}$-value $<0.05$, it is still significant. If the classroom learning environment indicators are associated with ease and acceptability of communication with an R-value of .647 with a p-value $<0.05$, this means still significant. Finally, when the indicators of the classroom learning environment are correlated with classroom observations with a total R-value of .663 with a p-value of $<0.05$, it is still significant.

\section{Significant Relationship Between Interactions of Students and Communicative Skills}

A significant relationship between the interaction of students and communicative ability. Table 5.3 with a total R-value of .803 and the corresponding probability of $p<.000$ is less than the 0.05 level of significance. The null hypothesis is unacceptable and states the significant correlation between the interaction of the students and communicative ability. Therefore, suggested that very high levels of the classroom learning environment can result in very high levels of communicative skills. It is noteworthy that the data showed that learning preference, school preference, effort and perseverance, extracurricular activities, and cognitive participation were indicators of students' engagement when correlated with instructional methodology; the total R-value is .692 with a p-value $<0.05$. therefore, significant.

Table 5.3

Significant Relationship Between Student Interaction and Communicative Ability

\begin{tabular}{|c|c|c|c|c|c|c|c|}
\hline \multirow{2}{*}{$\begin{array}{c}\text { Students } \\
\text { Interaction }\end{array}$} & \multicolumn{7}{|c|}{ Communicative Ability } \\
\hline & PM & PW & GG & IK & PI & $\mathrm{OK}$ & Total \\
\hline Learning Preference & $\begin{array}{l}.553^{* *} \\
.000\end{array}$ & $\begin{array}{l}.601^{* *} \\
.000\end{array}$ & $\begin{array}{l}.585^{* *} \\
.000\end{array}$ & $\begin{array}{l}.556^{* *} \\
.000\end{array}$ & $\begin{array}{l}.610^{* * *} \\
.000\end{array}$ & $\begin{array}{l}.633^{* *} \\
.000\end{array}$ & $\begin{array}{l}.666^{* *} \\
.000\end{array}$ \\
\hline School Preference & $\begin{array}{l}.523^{* *} \\
.000\end{array}$ & $\begin{array}{l}.592^{* *} \\
.000\end{array}$ & $\begin{array}{l}.484^{* *} \\
.000\end{array}$ & $\begin{array}{l}.581^{* *} \\
.000\end{array}$ & $\begin{array}{l}.614^{* *} \\
.000\end{array}$ & $\begin{array}{l}.627^{* *} \\
.000\end{array}$ & $\begin{array}{l}.641^{* *} \\
.000\end{array}$ \\
\hline $\begin{array}{l}\text { Effort and } \\
\text { Perseverance }\end{array}$ & $\begin{array}{l}.612^{* *} \\
.000\end{array}$ & $\begin{array}{l}.674^{* *} \\
.000\end{array}$ & $\begin{array}{l}.569^{* *} \\
.000\end{array}$ & $\begin{array}{l}.608^{* *} \\
.000\end{array}$ & $\begin{array}{l}.660^{* *} \\
.000\end{array}$ & $\begin{array}{l}.663^{* *} \\
.000\end{array}$ & $\begin{array}{l}.706^{* *} \\
.000\end{array}$ \\
\hline $\begin{array}{l}\text { Extracurricular } \\
\text { Activities }\end{array}$ & $\begin{array}{l}.443^{* *} \\
.000\end{array}$ & $\begin{array}{l}.438^{* *} \\
.000\end{array}$ & $\begin{array}{l}.398^{* *} \\
.000\end{array}$ & $\begin{array}{l}.430^{* *} \\
.000\end{array}$ & $\begin{array}{l}.468^{* *} \\
.000\end{array}$ & $\begin{array}{l}.399^{* *} \\
.000\end{array}$ & $\begin{array}{l}.486^{* *} \\
.000\end{array}$ \\
\hline $\begin{array}{l}\text { Informational } \\
\text { Participation }\end{array}$ & $\begin{array}{l}.670^{* * *} \\
.000\end{array}$ & $\begin{array}{l}.656^{* *} \\
.000\end{array}$ & $\begin{array}{l}.581^{* *} \\
.000\end{array}$ & $\begin{array}{l}.665^{* *} \\
.000\end{array}$ & $\begin{array}{l}.715^{* *} \\
.000\end{array}$ & $\begin{array}{l}.708^{* *} \\
.000\end{array}$ & $\begin{array}{l}.757^{* *} \\
.000\end{array}$ \\
\hline Total & $\begin{array}{l}.692^{* *} \\
.000\end{array}$ & $\begin{array}{l}.729^{* * *} \\
.000\end{array}$ & $\begin{array}{l}.646^{* * *} \\
.000\end{array}$ & $\begin{array}{l}.701^{* *} \\
.000\end{array}$ & $\begin{array}{l}.758^{* *} \\
.000\end{array}$ & $\begin{array}{l}.742^{* * *} \\
.000\end{array}$ & $\begin{array}{l}.803^{* *} \\
.000\end{array}$ \\
\hline
\end{tabular}

*Significant at .05 significant level 
Legend:

PM - teaching methods

PW - teacher's perspective

GG - teacher role

IK - the impact of communicative language teaching on communicative ability

PI - ease and acceptable communication

OK - classroom observations

When the indicators of student engagement were compared to those of teachers, the total R-value was.729 with a p-value of 0.05 . When students' interactions with teacher roles were correlated, the total R-value was.646, with a p-value of 0.05 . When indicators of student engagement are compared to the effect of communicative instruction on communicative ability, the total R-value is.701 with a p-value of 0.05 , indicating that the relationship is still significant. Suppose the indicators of students' interaction with the ease and acceptability of communication are correlated have a total $\mathrm{R}$-value of 0.758 and a $\mathrm{p}$-value of 0.05 . In that case, this indicates that the correlation is significant. When indicators of student interaction with class observations have a total R-value of 0.742 and an a-value of 0.05 , the correlation is still substantial.

Significantly Combined and Single Influence of Teaching Ability of Teacher, Classroom Learning and Student Interaction with Communicative Ability

Table 6 presents the significant and single influence of teacher teaching ability, classroom learning, and students' engagement on communicative ability, with a calculated F-value of 369.015, an R-value of.846, an adjusted R2 value of.717, and a p-value of.000, which is less than the 0.05 level of significance. The overall result rejected the null hypothesis that supported the alternative hypothesis.

Table 6

Significant Combined and Single Influence of Teacher Teaching Ability, Classroom Learning and Student Interaction on Communicative Ability

\begin{tabular}{lcccc}
\multicolumn{5}{c}{ Student Interaction on Communicative Ability } \\
\hline \multicolumn{1}{c}{ Exogenous Variables } & \multicolumn{1}{c}{ Communicative Ability } & & \\
& $B$ & $\beta$ & $t$ & Sig. \\
Constant & .333 & & 2.667 & .008 \\
Teacher Teaching & .348 & .343 & 8.661 & .000 \\
Ability & .061 & .060 & 1.367 & .172 \\
Classroom Learning & .520 & .520 & 12.771 & .000 \\
Student Satisfaction & & &
\end{tabular}

$\begin{array}{cc}\mathrm{R} & .846 \\ \mathrm{R}^{2} & .717 \\ \Delta \mathrm{R} & .715 \\ \mathrm{~F} & 369.015 \\ \rho & .000\end{array}$


Therefore, the three exogenous variables have a significant influence on communicative ability. An R2 of .717 indicated $71.7 \%$ of differences in communicative ability associated with teaching ability, classroom learning environment, and communication relationship of students. This means that $28.3 \%$ of the variation of communicative ability was attributed to other variables not covered in this study. On closer examination, the table shows that of the three exogenous variables, students 'interaction had the largest contribution $($ Beta $=.520, \mathrm{P}$-value $=.000)$ followed by teaching ability $($ Beta $=.348, \mathrm{P}$-value $=.000)$ and the lowest was the classroom learning environment $($ Beta $=.061$, $\mathrm{P}$-value $=.172)$. Of the three variables, only students 'interaction and teaching ability significantly influenced communicative ability.

It can be seen from the data that the classroom learning environment has standardized and unstandardized coefficients of .061 and .060, t-value of 1.367 and p-value of .172 (nonsignificant); teaching ability has standardized and unstandardized coefficients of .348 and $.343, \mathrm{t}-$ value of 8.661 and p-value of .000 (Significant); and student interaction had standardized and unstandardized coefficients of .520 and .520 , t-value of 12.771 and p-value of .000 (Significant).

Table 8

Direct and Indirect Effects of Independent Variables on the Communicative Ability of Students of the Most Appropriate Model

\begin{tabular}{lccc}
\hline Variables & Direct Effect & Indirect Effect & Total Effect \\
\hline $\begin{array}{l}\text { Teacher Teaching } \\
\text { Ability }\end{array}$ & .510 & .114 & .624 \\
Classroom Learning & - & .806 & .806 \\
Student Satisfaction & .430 & - & .430 \\
\hline
\end{tabular}

\section{Establishing the Most Appropriate Structural Model}

The final question addressed by this research is which model best represents variables as predictors of students' communicative ability. The five models developed in this study are summarized in Table 7. Additionally, it demonstrates the proposed framework's modification. Table 1 satisfies the requirement for the goodness of fit measures.

The Chi-square/degrees of freedom value must be between 0 and 2, with a corresponding p-value greater than or equal to 0.05. The Error's Root Mean Square The approximate value must be less than 0.05 and be greater than or equal to the corresponding p-close value. Other indices, including the Normed Fit Index, the Tucker-Lewis Index, the Comparative Fit Index, and the Goodness of Fit Index, must be greater than 0.90.

The resulting Structural Model 1 demonstrates a causal relationship between exogenous variables: teaching ability, classroom learning environment, and students' interactions with the endogenous variable communicative ability. Certain calculated signs in this model have difficulty attaining acceptable value ranges; thus, this model is ineffective. 
EPRA International Journal of Multidisciplinary Research (IJMR) - Peer Reviewed Journal

Volume: 8| Issue: 1| January 2022|| Journal DOI: 10.36713/epra2013 || SJIF Impact Factor 2021: 8.047 || ISI Value: 1.188

Table 7

Summary of Goodness of Fit Measures of Five Structural Models

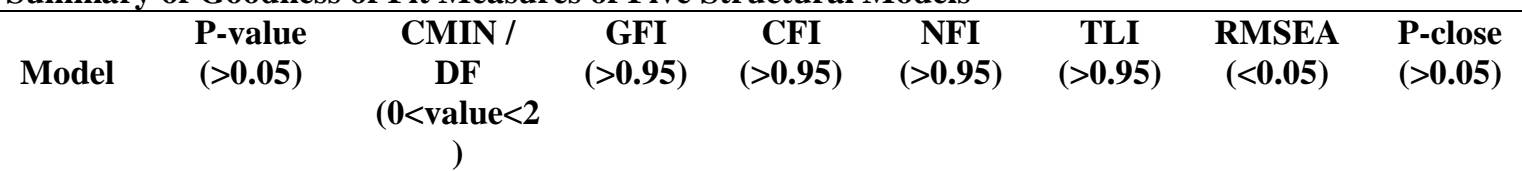

\begin{tabular}{|c|c|c|c|c|c|c|c|c|}
\hline 1 & .000 & 10.581 & .759 & .813 & .798 & .783 & .147 & .000 \\
\hline 2 & .000 & 6.545 & .839 & .893 & .877 & .875 & .112 & .000 \\
\hline 3 & .000 & 4.176 & .872 & .939 & .922 & .928 & .085 & .000 \\
\hline 4 & .000 & 4.845 & .851 & .926 & .908 & .913 & .093 & .000 \\
\hline 5 & .060 & 1.339 & .978 & .996 & .986 & .994 & .028 & .989 \\
\hline
\end{tabular}

Legend:

CMIN/DF - Chi-Square/Degrees of Freedom

GFI $\quad-$ Goodness of Fit Index

RMSEA - Root Mean Square of Error Approximation

\author{
NFI -Normed Fit Index \\ TLI -Tucker-Lewis Index \\ CFI - Comparative Fit Index
}

The generated Structural Model 2 demonstrates a direct causal relationship of exogenous variables teaching ability, classroom learning environment, students' interaction, and endogenous variable communicative ability. This model is not suitable because p-value $=.000$ and RMSEA $=.112$ with $\mathrm{p}$-close $=.000$, all index values are not achieved on each premise.

The generated Structural Model 3 also shows a direct causal relationship of teaching ability and students' interaction towards communicative ability. The result is inappropriate because $\mathrm{p}$-value $=.000$ and RMSEA $=$ .085 with p-close $=.000$.

The generated Structural Model 4 shows the direct causal relationship of the classroom learning environment to communicative ability. The result is inappropriate as indicated p-value $=.000$, RMSEA $=.093$ with p-close value $=.000$.

Finally, the generated Structural Model 5 demonstrates the direct causal correlation of teaching ability and students' engagement towards communicative ability as identified in the most appropriate model. The most appropriate model is in Table 7. The Chi-Square divided by degrees of freedom is 1.339 with a P-value of .060 . It indicates the model. The Root Means Square of Error Approximation index is .028 is less than the 0.05 significance level with a related P-close of .989. Also, other indexes such as the Normed Fit Index, TuckerLewis Index, and Comparative Fit are highly indicative of the most appropriate model because of all measurements from the criteria. Table 8 shows the direct effects arrows from the predictor variables presented on the left side to the right side where the non-independent variable does not pass through the other variable.

Indirect effects are the correlation of the predictor of the variable and the non-independent variable that may mediate one or more variables. Presented in Table 9, the effect of the latent variable and between the indicator, in the latent variable estimated to generate regression in teaching ability, classroom learning environment, and student engagement significantly affect the endogenous variable that communicative ability ( $p$ $<.05)$.

A summary of the goodness of fit measures of the five structural models is presented in Table 10.

Table 10

Goodness of Fit Structural Measures of the Most Fit Model

INDEX CRITERION

MODEL FIT VALUE

P-value $\quad>0.05$

CMIN/DF

$0<$ value $<2$

GFI

$>0.95$ 


\section{Legend:}

$\begin{array}{ll}\text { CMIN/DF } & - \\ \text { NFI } & - \\ \text { TLI } & - \\ \text { CFI } & - \\ \text { GFI } & - \\ \text { RMSEA } & - \\ \text { P-close } & -\end{array}$

\author{
Chi-Square/Degrees of Freedom \\ Normed Fit Index \\ Tucker-Lewis Index \\ Comparative Fit Index \\ Goodness of Fit Index \\ Root Means Square of Error Approximation \\ P of Close Fit
}

\section{SUGGESTION}

The researcher made the following recommendations in light of the findings: The extremely high level of teaching ability, classroom learning environment, student engagement, and communicative ability that the three variables on which students focus increase the level of communicative ability. This, however, will facilitate the implementation of measures relating to communicative ability. The extremely high level of teaching ability, classroom learning environment, student interaction, and communicative ability as measured by their respective indicators all contribute significantly to demonstrating the usefulness of this research as a guide for students and will serve as the inspiration for the Department of Education and the Commission of Higher Education to assist researchers in being successful. Thus, the outcome of this study will be highly beneficial in terms of honing each student's communication skills. It will be the start of a series of exercises aimed at maintaining or improving each participant's level of communicative ability.

The researcher made the following recommendations in light of the findings: The extremely high level of teaching ability, classroom learning environment, student engagement, and communicative ability that the three variables on which students focus increase the level of communicative ability. This, however, will facilitate the implementation of measures relating to communicative ability. The extremely high level of teaching ability, classroom learning environment, student interaction, and communicative ability as measured by their respective indicators all contribute significantly to demonstrating the usefulness of this research as a guide for students and will serve as the inspiration for the Department of Education and the Commission of Higher Education to assist researchers in being successful. Thus, the outcome of this study will be extremely beneficial in terms of honing each student's communication skills. It will be the start of a series of exercises aimed at maintaining or improving each participant's level of communicative ability.

The extremely positive outcome of this study will benefit students directly by allowing them to improve their communicative ability through researching the indicators and variables examined in this study. As such, serve as their guide and assist the researcher in developing effective holistic strategies based on a thorough understanding of the fundamental structural model of students' communicative ability. Additionally, this study has a high potential for replication due to the extremely high level of each variable. Additionally, they can conduct training sessions or seminars on public speaking or communication.

\section{CONCLUSION}

Using the structural model to reinforce the study proved to be extremely difficult. It was subjected to rigorous evaluation and followed specifications, discrimination, and evaluation models. It demonstrates an exceptional ability to teach, a positive classroom learning environment, and high levels of student engagement. According to the various literature presented in the relationship between each variable, there is a significant relationship between teaching ability, classroom learning environment, student interaction, and communicative ability. Only the fifth structural model, discovered in this study, exhibits an exceptional fit to the data, making it the most appropriate structural model. 
However, a communicative ability associated with various factors such as teacher teaching ability, classroom learning, and student engagement can serve as a starting point for evaluating and encouraging students' change toward learning (Williams and Burde, 1997). There was a significant correlation between student interaction and communicative ability, as some writers hypothesized that productive student engagement would create a unique learning environment through teachers' inherent teaching ability (Turner, 2004). The most appropriate model demonstrates that teaching ability, classroom learning environment, and student engagement are the most effective predictors of communicative ability, indicating increased student interest.

\section{REFERENCES}

1. Bacon, L. D. (1998). Using Amos for structural equation modeling in market research. https://www.bauer.uh.edu/jhess/documents/3.pdf.

2. Bergil, A. (2016). "The influence of willingness to communicate on overall speaking skills $\quad$ among EFL learners. Procedia-Social and Behavioral Sciences, 232, 177-187. https://doi.org/10.1016/j.sbspro.

3. Bollen, K. A., F. Chen, P. J. Curran, J. Kirby and P. Paxton (2008). An empirical evaluation of the use of fixed cut-off points in RMSEA test statistic in structural equation models.

4. Byrne, B. M. (2012). Structural equation modeling with Mplus: Basic concepts, applications, and programming. New York: Taylor \& Francis/Routledge. Ottawa University.

5. Darko, K., A. Denkabe, and B. E. Forson. (1997). The Ghanaian University students' knowledge of grammar. In Dakubu, Kropp, M. E., (ed), English in Ghana. Accra: Ghana, English Studies Association.

6. David, F. (2002). Understanding and Doing Research: A Handbook for Beginners. Iloilo City: Social Science Institute, $C P U$.

7. Felicilda, J, A. Felicilda, and R. E. Tabañag (2019). Common problems in oral communication skills among high school students. SMCC teacher education Journal.

8. Fraenkel, J. R. and H. H. Hyun. (2012). How to design and evaluate research in education (8th edition). New York, NY: Mc Graw Hill Companies, Inc.

9. Gill, P. S. (2012). An investigation of employee engagement and business outcomes at an engineering services firm. Eastern Michigan University: ProQuest Dissertation Publishing.

10. Hasman, Arie. (2015). An introduction to structural equation modeling. In ICIMTH.

11. Kirinić, A. J. Dvorski and L. Bakić-Tomić. (2015). Elements of teacher communication competence: An examination of skills and knowledge to communicate. International Journal of Research in Education and Science (IJRES).

12. Ogunlana, S., D. R. Ogunsami and A. E. Oke. (2017). Establishing a common ground for the use of structural equation modelling for construction related research studies. Australasian Journal of Construction Economics and Buildings, 12(3), 8994. https://www.researchgate.net/publication/28102462.

13. Owusu-Ansah, E. (2015). Dativization and the maintenance of standards in non-native varieties of English, in Dakubu (ed.). English in Ghana.

14. Savalei, V. and P. M. Bentler. (2010). Structural equation modeling. The Corsini Encyclopedia of Psychology.

15. Sergiovane, M. (2015). Applied organizational relations: cases in stakeholder management in educational setting. British Journal of Education.

16. Turner, C., R. McClure and S. Pirozzo. (2004). Injury and risk-taking behavior - A systematic review. accident analysis and prevention.

17. Ullman, J. B. and P. M. Bentler. (2012). Structural equation modeling (SEM). Part Four. data analysis methods.

18. Von Der Heidt, T. and D. R. Scott. (2007). Partial aggregation for complex structural equation modelling (SEM) and small sample sizes: An illustration using multi-stakeholder model of cooperative inter-organizational relationships (IORs) in product innovation' presented to the 21st ANZAM 2007 Conference, Sydney.

19. Williams, M., and R. Burde. (1997). Psychology for language teacher: A social constructivist approach. Cambridge: Cambridge University Press. https://doi:10.1007/978-0-387-75734-6_5. 